University of Nebraska - Lincoln

DigitalCommons@University of Nebraska - Lincoln

\title{
Social Immunity and the Superorganism: Behavioral Defenses Protecting Honey Bee Colonies from Pathogens and Parasites
}

\author{
Michael Simone-Finstrom \\ Honey Bee Breeding, Genetics and Physiology Laboratory, USDA-ARS, \\ Michael.SimoneFinstrom@ars.usda.gov
}

Follow this and additional works at: https://digitalcommons.unl.edu/usdaarsfacpub

Simone-Finstrom, Michael, "Social Immunity and the Superorganism: Behavioral Defenses Protecting Honey Bee Colonies from Pathogens and Parasites" (2017). Publications from USDA-ARS / UNL Faculty. 2317.

https://digitalcommons.unl.edu/usdaarsfacpub/2317

This Article is brought to you for free and open access by the U.S. Department of Agriculture: Agricultural Research Service, Lincoln, Nebraska at DigitalCommons@University of Nebraska - Lincoln. It has been accepted for inclusion in Publications from USDA-ARS / UNL Faculty by an authorized administrator of DigitalCommons@University of Nebraska - Lincoln. 
Social Immunity and the

\section{Superorganism: Behavioral Defenses Protecting Honey Bee Colonies from Pathogens and Parasites}

\section{Michael Simone-Finstrom}

\section{Introduction}

Understanding the complexities of social insect immunity, that is, how insects combat pathogens, parasites and pests, is a fundamental question that not only has broad applications for understanding disease dynamics in social groups (Fefferman $\&$ Traniello, 2008) (e.g., human societies) but also practical benefits for improving honey bee stocks for increased health and productivity. When we first consider the concept of immunity in any organism, the tendency is to think at the level of the individual organism and focus on physical barriers (e.g., the honey bee cuticle) and individual physiological defenses that are largely induced in response to pathogens that get past the initial defenses (e.g., antimicrobial peptides in the bee hemolymph). For honey bees (specifically Apis mellifera in this discussion) and other social insects, however, the colony is often the unit of evolutionary selection (Seeley, 1997). Combined efforts of individual honey bees promote colony productivity and survival; thus individuals in that colony survive to successfully spread their genetics through subsequent generations via the production of drones, swarms, and queens.

In many ways, immunity in social insects exemplifies the superorganism concept, whereby there is an immune system in individual bees, but there is also a colony-level immune system. Both function to promote survival not only of an individual bee but also of the colony. Given the reduction in immune genes that has now been noted for honey bees and Hymenoptera in general (Barribeau et al., 2015; Evans et al., 2006; Gadau et al., 2012; Simola et al., 2013), it seems as though the evolution of numerous colony-level, largely behavioral mechanisms has occurred either to compensate for the reduced investment in physiological immunity or as a result of the reliance on colony-level defenses relaxing the selection pressure for a stronger individual immune defense (Harpur \& Zayed, 2013).

Traits that reduce pathogen and parasite infection intensity and transmission at the colony level are referred to as "social immunity" (Cremer, Armitage, \& SchmidHempel, 2007). Recent iterations have been proposed to expand the definition of social immunity to apply to not just eusocial organisms (i.e., ants, honey bees) but to include parental care and group-living species in general (Cotter \& Kilner, 2010). Meunier (2015) further clarified this expansion to define social immunity as any defense against parasites and pathogens that evolved and is maintained due to the benefits derived by group members. In this way social immunity is limited to traits that ultimately express at least some level of benefit to the colony or superorganism.

Analogies can be made between mechanisms of individual and social immune defense, which also sheds light on the superorganism concept (Cremer \& Sixt, 2009). One clear example would be the analogy of cellular encapsulation, which involves hemocytes in the bee's hemolymph surrounding a microbe that has penetrated into a bee's system. These cells surround the microbe and produce cytotoxic compounds to destroy it, thus preventing it from further infecting the individual bee. This is analogous to what happens in Apis ceranae japonica colonies that are attacked by the Japanese hornet (Vespula mandarinia japonica). These hornets invade the honey bee colony and individual bees (e.g., the cellular hemocytes of the superorganism) tightly surround and "ball" the hornet, killing it by generating heat and carbon dioxide to suffocate the hornet and preventing colony infestation (Sugahara \& Sakamoto, 2009).

Due to the connections between individual, physiological immunity and colony-level social immune mechanisms, common terminology for how these traits are expressed is also being adopted (Cremer \& Sixt, 2009). These mechanisms function across a gradient of constitutive immune defenses to those that are highly inducible (Figure 1). Constitutive defenses are those that are constantly present and therefore remain relatively static in the background and do not change when individuals or colonies are exposed to pathogens. Inducible defenses are those that are activated upon the presence of pathogens or parasites. All immune defenses lie somewhere along this gradient, and each can play a crucial role in the overall colony or social immune system.

This article aims to describe mechanisms of social immunity that honey bees use to reduce the spread of pathogens and parasites at the colony level. The initial description and recent reviews of social immunity tended to structure discussions of the different defenses around parasite exposure (starting with limiting parasite uptake at the individual level and ending with reducing spread of pathogens within and across colonies) (Cremer et al., 2007; Meunier, 2015). In their foundational work, Cremer and colleagues (2007) then separated discussion within the defenses as "prophylactic measures and activated responses;" here the term constitutive replaces prophylactic and inducible replaces activated to merge the terminologies associated with physiological immunity and better facilitate connections with descriptions of social immunity. Moving forward in the discussion of the evolution of social immune defenses, investigations 


\section{Constitutive Mechanisms}

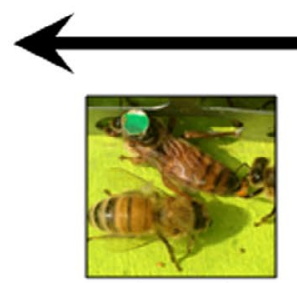

Polyandry

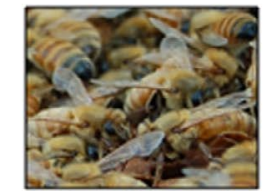

Task allocation
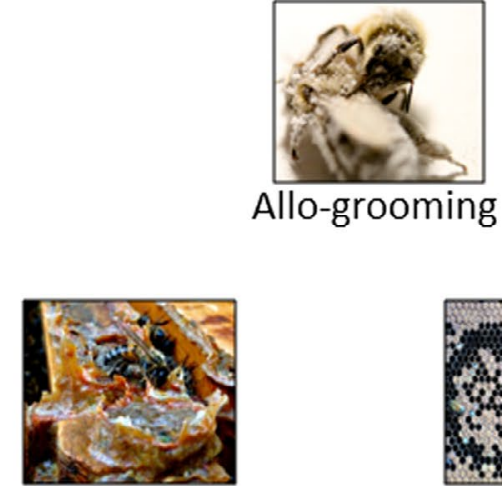

Resin use

(Propolis)
Inducible Traits
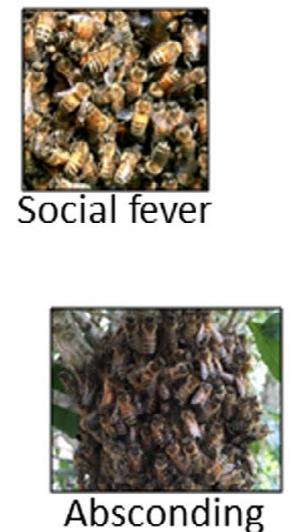

Transfer of compounds and microbiota

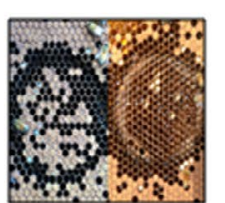

Hygienic behavior

Figure 1. Overview of social immunity in honey bees. Traits are depicted on the continuum from highly constitutive (prophylactic) to highly inducible (activated by pathogen exposure).

All photos were taken by M. Simone-Finstrom.

into how colonies invest in constitutive versus inducible defenses should be at the forefront. As there are costs and benefits associated with reliance on different types of defenses, this aspect needs to be more fully considered with respect to social immunity as it has for individual, physiological immunity (Adamo, Davies, Easy, Kovalko, \& Turnbull, 2016; Hamilton, Siva-Jothy, \& Boots, 2008; Westra et al., 2015). With this in mind, the review presented here uses the gradient of constitutive effects to induced effects (Figure 1) as the framework for discussion.

\section{Polyandry and the Case for Genetic Diversity}

Honey bees colonies are headed by one queen that mates early in her life with numerous different males (Ruttner, 1956), and is responsible for producing all of the workers that comprise the colony. Multiple mating of the queen is referred to as polyandry (i.e. many fathers). The number of males that the queen mates with determines the number of patrilines or subfamilies within a colony, which in turn determines the level of genetic diversity. The more mates a queen has the more genetically diverse her offspring are. Queens typically mate with 5 to 35 males (average 14) (Tarpy, Nielsen, \& Nielsen, 2004; Tarpy, vanEngelsdorp, \& Pettis, 2013), which results in some colonies having relatively low genetic diversity and some having extremely high levels.

Because the queen cannot choose to mate after her initial mating flights, the genetic diversity is essentially set for a colony unless the colony replaces that queen. Given this, genetic diversity plays a background role in colony health and productivity, albeit a significant one. Colonies with increased levels of genetic diversity have been shown to have increased foraging efficiency (Eckholm, Anderson, Weiss, \& DeGrandi-Hoffman, 2011), healthier gut microbial communities (Mattila, Rios, Walker-Sperling, Roeselers, \& Newton, 2012), overall increased fitness and productivity (Mattila \& Seeley, 2007), and better survival in commercial beekeeping operations (Tarpy et al., 2013). From a disease perspective, colonies with higher levels of genetic diversity are more resistant to disease and have infections of less intensity (Bailey, 1999; Tarpy, 2003; Tarpy \& Seeley, 2006). This at least in part could be due to larval immunity (Invernizzi, Penagaricano, \& Tomasco, 2009; Palmer \& Oldroyd, 2003; Simone-Finstrom, Walz, \& Tarpy, 2016) or even general immunocompetence (López-Uribe, Appler, Dunn, Frank, \& Tarpy, 2017), but also likely has broader effects on multiple traits of resistance. Further, colonies with increased levels of genetic diversity are likely better able to combat exposure to multiple pathogens and parasites and different strains of a single pathogen (Bailey, 1999; Evison et al., 2013; Lee, McGee, \& Oldroyd, 2013; Vojvodic, Jensen, Markussen, Eilenberg, \& Boomsma, 2011). There does seem to be a point at which higher levels of genetic diversity do not confer a greater advantage (Simone-Finstrom, Foo, Tarpy, \& Starks, 2014; Simone-Finstrom et al., 2016; Wilson-Rich, Tarpy, \& Starks, 2012), which has raised the question as to why queens frequently mate with such a large number of males (i.e., more than 5-7) (Palmer \& Oldroyd, 2000). Rearing queens from the youngest larvae available results in larger queens that, on average, mate with more males (Tarpy, Hatch, \& Fletcher, 2000; Tarpy, Keller, Caren, \& Delaney, 2011) and thus have more productive colonies (Rangel, Keller, \& Tarpy, 2013). This is one way to promote increased genetic diversity in managed colonies. In addition, ensuring adequate drone sources in mating yards is key for a queen to have access to large numbers of males during her mating flights.

\section{Task Allocation}

In addition to promoting task efficiency, the division of labor among workers has a constitutive effect against the spread of pathogens and parasites within colonies. Honey bee task is largely guided by bee age, which is known as temporal polyethism. Typically young adult worker bees first clean cells, then move to queen and brood care followed by transitioning to nest maintenance and nectar handling followed lastly by foraging (Johnson, 2010). The youngest bees perform the "inside" tasks and are thus shielded from disease and parasites outside of the colony. As bees switch to foraging-related tasks and are more at risk for exposure, they interact less and less with the younger bees. An exception would be "undertakers," bees that remove dead bees from the hive. Though these bees tend to be middle-aged, pre-foragers, they generally stay at the nest periphery and become foragers upon completion of this task and are therefore compartmentalized from 
the rest of the colony (Trumbo, Huang, \& Robinson, 1997). More thorough research on this subject has been done with ants, particularly leafcutting species that have designated waste piles and strong division of labor among individuals guarding and maintaining the trash heaps (Adam \& Francis, 2001; Bot, Currie, Hart, \& Boomsma, 2001). It is important to note that transitions between tasks are flexible in honey bees. If one age class dies (e.g., foragers being killed from a predatory event or pesticides), task and age can be uncoupled until the normal age structure is reset (Rueppell, Linford, Gardner, Coleman, \& Fine, 2008). Several studies have modeled the role that interactions between individuals and division of labor can play in the reduction of pathogen transmission (Baracchi \& Cini, 2014; Naug, 2008; Naug \& Camazine, 2002). The combined effects of buffering the queen from the more high-risk exposure individuals and compartmentalization of different tasks plays a factor in limiting disease transmission throughout a colony.

\section{Use of Antimicrobial Compounds}

\section{Honey Bee Use of Self-produced Compounds}

Insects produce various antimicrobial compounds to protect themselves from invading microbes. In social insects many of these compounds have multiple functions and in some cases they evolved as individual defenses that were then co-opted for a defense against pathogens and parasites at the colony level (Otti, Tragust, \& Feldhaar, 2014; Stow et al., 2007). Research is quickly developing in this area. For example, recent studies have found venom peptides on the honey bee's cuticle (Baracchi, Francese, \& Turillazzi, 2011). Venom has antimicrobial properties (Moreau, 2013), which suggests that spreading it on the bee cuticle may have direct effect against pathogens as has been shown in some ant species (Tragust et al., 2013). In addition, these compounds have also been found deposited in the comb, suggestive of a broader social immunity trait (Baracchi, Mazza, \& Turillazzi, 2012; Baracchi et al., 2011).

Another instance of compounds that are typically considered as an individual defense are the presence of antimicrobial peptides, like Defensin-1 (Klaudiny, Albert, Bachanová, Kopernický, \& Šimúth, 2005), and other compounds like glucose oxidase in the larval diet and honey (Ohashi, Natori, \& Kubo, 1999). While there is a lack of research on whether these specific compounds directly impact disease, there is evidence that some colonies invest in production of larval food that has a higher level of antimicrobial compounds, reducing colony infection levels, and that this is a heritable trait (Rose \& Briggs, 1969). Production of these compounds does seem to be constitutive, whereby it doesn't change in response to a pathogen challenge, and is simply differentially expressed at the colony level (López-Uribe \& Simone-Finstrom, 2017; Rose \& Briggs, 1969).

These antimicrobial secretions can also boost pathogen resistance if they are transferred via trophallaxis (bee to bee oral transfer) as has been seen in some ants and termites (Hamilton, Lejeune, \& Rosengaus, 2011; Mirabito \& Rosengaus, 2016). Similarly exchange of microbiota through trophallaxis or through consumption of hive products (Koch \& Schmid-Hempel, 2011; Powell, Martinson, Urban-Mead, \& Moran, 2014) may influence disease susceptibility and could also be a factor in colony-level resistance to pathogens. Future research should be conducted to determine the role that these behaviours play in social immunity.

\section{Collection and Use of Plant-based \\ Defensive Compounds}

Production of antimicrobial compounds can be energetically costly and the ability to produce certain compounds is evolutionarily constrained based on the organism's biology. To overcome this, many species harvest and utilize defensive compounds produced by other organisms, mainly plant-based defenses. The collection and use of plant-produced resins within a honey bee nest is a prime example. Various trees and woody shrubs produce chemically complex resins to protect leaf buds and seal wounds against their pathogens and pests (Langenheim, 2003). Honey bees forage for these resins, mix them with varying amounts of wax and incorporate them into their nest architecture, at which point the mixture is referred to as propolis (Ghisalberti, 1979; Seeley \& Morse, 1976; Simone-Finstrom \& Spivak, 2010). Much of the work on propolis has focused on the plant sources and chemical properties of propolis and its potential for use in development of new drugs for human use (Bankova, de Castro, \& Marcucci, 2000; Bankova \& Marcucci, 2000; Sforcin \& Bankova, 2011; Silva-Carvalho, Baltazar, \& AlmeidaAguiar, 2015; Wilson, Spivak, Hegeman, Rendahl, \& Cohen, 2013); though in recent years there has been increasing interest in the effects that propolis has on honey bee health and productivity.

In feral colonies nesting in tree cavities, bees line the entire nest interior with a thin layer of propolis, while bees in managed, smooth boxes tend to patchily distribute the resin. In both cases, more resin does appear to be deposited at the nest entrance, which may function as an initial barrier but also physically reduces
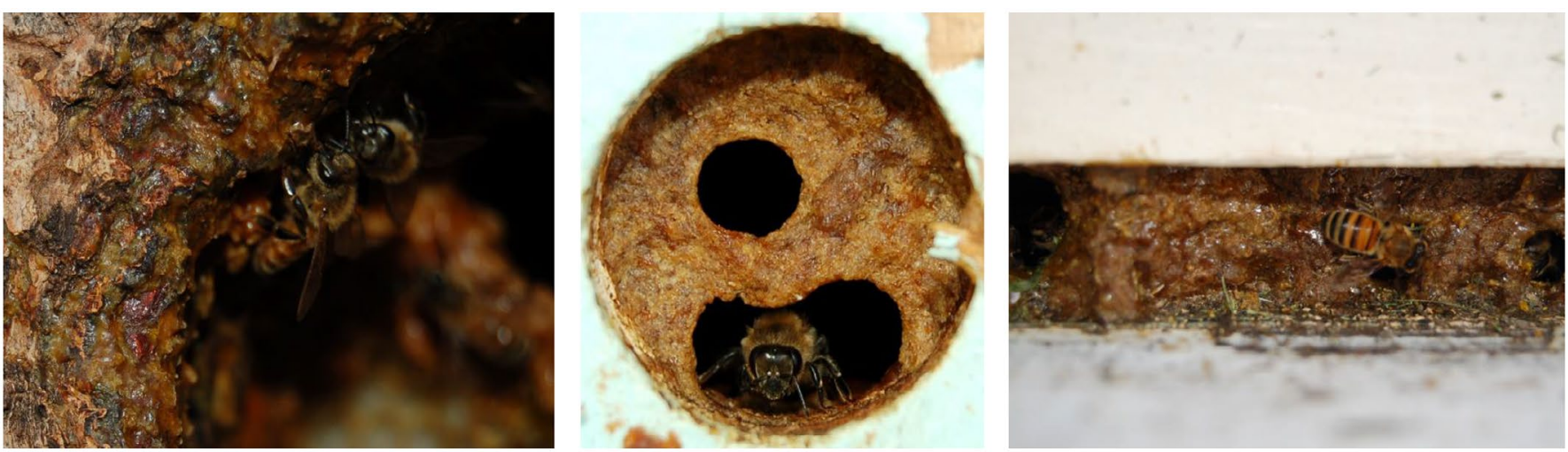

$\Delta$ Figure 2. Propolis at nest entrances. Honey bees tend to deposit appreciable resin at the nest entrance in both feral (left) and managed colonies (middle, right). This can serve multiple purposes, including providing an initial barrier against pathogens and parasites or simply by physically reducing entrance size.

All photos were taken by M. Simone-Finstrom. 
the entrance (Figure 2). Resin-enriched colonies have a lower overall microbial load resulting in bees that can relax their immune system (Simone, Evans, \& Spivak, 2009). Since high expression of the immune system can reduce colony productivity (Evans \& Pettis, 2005), this reduction in investment of the individual immune system can have benefits at the colony level (Borba, Klyczek, Mogen, \& Spivak, 2015). Additionally propolis in the hive can exhibit direct effects against brood pathogens, namely the American foulbrood bacterium and the chalkbrood fungus (Antúnez et al., 2008; Borba, 2015; Lindenfelser, 1968; Simone-Finstrom \& Spivak, 2012), likely from the volatile chemical components. Additional evidence suggests that colonies in one region exhibiting natural resistance to the parasitic mite Varroa destructor collect resins rich in particular bioactive compounds and that this could be one mechanism of mite resistance in this population (Popova, Reyes, Le Conte, \& Bankova, 2014). Research on Africanized honey bees in Brazil has shown that colonies bred for increased resin collection (Nicodemo, Malheiros, De Jong, \& Couto, 2014) have an increased brood production and bees with longer lifespans. The consistency of this effect needs to be tested more thoroughly, particularly with bees in the US where propolis production has been historically selected against (Fearnley, 2001). Much of this selection against propolis has been because beekeepers have been unaware of the health benefits of propolis and so breeder colonies without frames coated in sticky propolis have been preferred.

While effects of a propolis-rich environment occur more in the background, influencing colony microbial levels and perhaps modulating immune function, there is evidence that honey bees do induce resin collection in response to chalkbrood, but not American foulbrood (Borba, 2015; Simone-Finstrom \& Spivak, 2012). In this way, the collection of resin is a unique type of self-medication operating at the colony or superorganism level. Adult honey bees, which cannot be infected by chalkbrood, increase collection of antimicrobial resins to protect other colony members (i.e., larvae) from infection. Additional research suggests that honey bee colonies may also "self-medicate" against the parasitic Varroa mite and Deformed wing virus (Drescher, Klein, Neumann, Yañez, \& Leonhardt, 2017), and so this behavior could be influenced at multiple levels of infection and infestation. Mechanisms influencing resin collection and its deposition need to be more fully investigated to understand how bees invest in this as a form of defense, both constitutively and after exposure to pathogens.

The use of propolis by honey bees against the pest small hive beetle needs to be described more broadly as well. Colonies of A. mellifera capensis in South Africa have been noted to encapsulate small hive beetles in "propolis prisons" where they remain confined (Neumann et al., 2001). The effectiveness of this behavior for controlling small hive bees in European honey bee colonies appears to be less clear (Ellis, Hepburn, Ellis, \& Elzen, 2003). As propolis deposition is a heritable trait, breeding efforts to increase resin collection would help to further explore the role that it has as a social immune defense against honey bee pests.

Antimicrobial compounds found in nectar, namely secondary plant metabolites like alkaloids, are also collected during foraging. Honeys made from different nectar sources have different antimicrobial profiles. As incoming nectar is stored

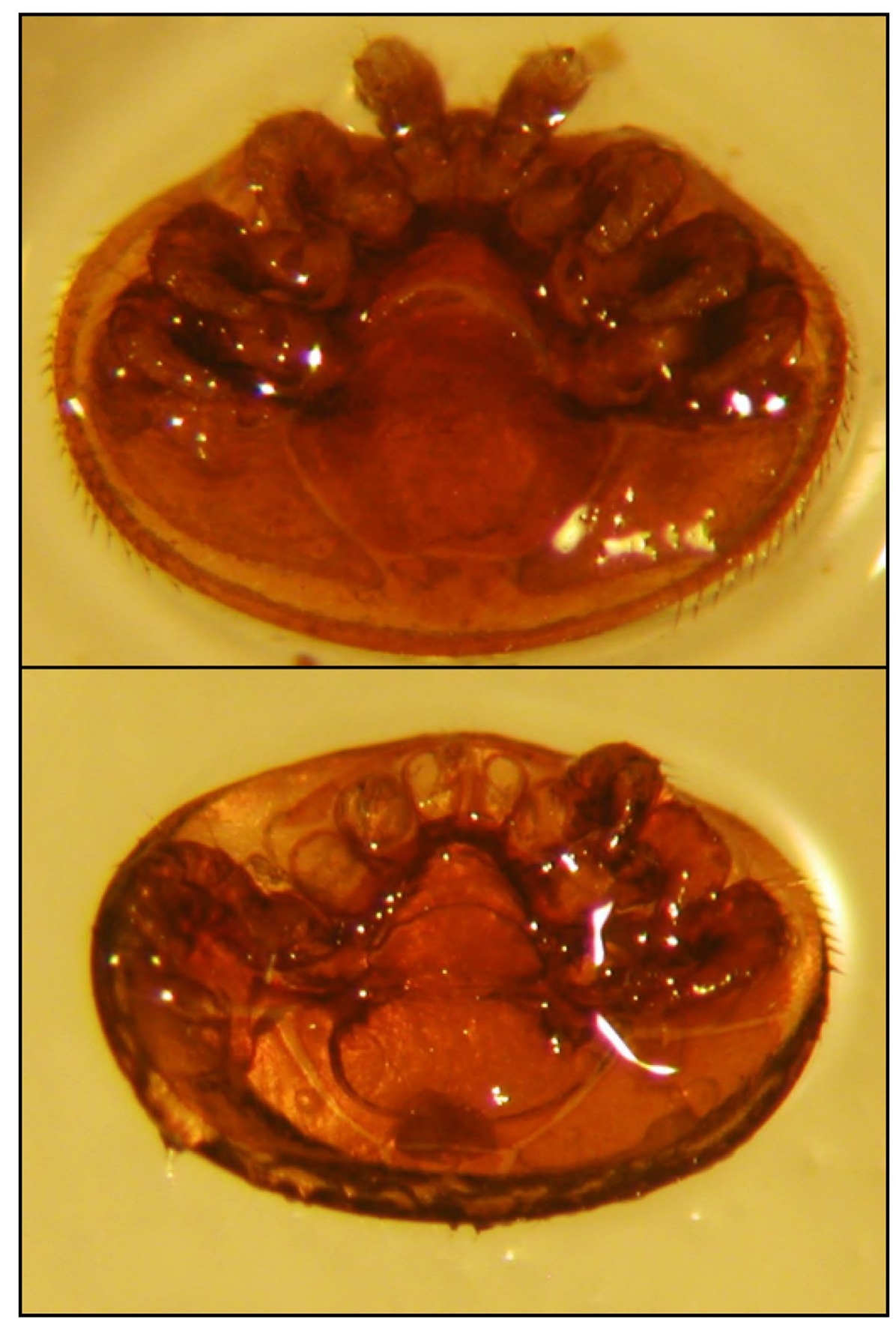

$\Delta$ Figure 3. Varroa is susceptible to grooming damage. Grooming often results in chewed legs or other damage to the mite cuticle (top: undamaged mite; bottom: mite with several legs removed). USDA photos. 
and converted into honey, it is mixed from various sources. The resulting diversity in antimicrobial activities of the stored honey is hypothesized to have an effect on colony-level disease expression (Erler, Denner, Bobiş, Forsgren, \& Moritz, 2014). There is also some evidence that honey bees infected with the microsporidian gut parasite Nosema have a preference for honey with higher antimicrobial properties (Gherman et al., 2014). While it is currently unclear what effect this may have at the colony-level, these findings raise important questions about the universality of "self-medication" in insects (Erler \& Moritz, 2016).

\section{Grooming}

Grooming is generally a first line of defense against invading microorganisms (Zhukovskaya, Yanagawa, \& Forschler, 2013). Honey bees both auto-groom (selfgroom) and participate in allo-grooming (grooming of nestmates). From the perspective of social immunity, grooming can have two major effects. The first is on ectoparasites, particularly mites such as tracheal mites Acarapis woodi and $V$. destructor that infest honey bee colonies. For tracheal mites it appears that auto-grooming is the major defense preventing individual infection (Danka \& Villa, 1998; Pettis \& Pankiw, 1998) and grooming of these mites at the individual level can effectively eliminate the mites at the colony level. For Varroa, there is evidence that response and subsequent damage to the mites during grooming (see Figure 3) can be an aspect of colony-level mite resistance that has undergone both natural selection and artificial selection through breeding (Arechavaleta-Velasco, Alcala-Escamilla, Robles-Rios, Tsuruda, \& Hunt, 2012; Boecking \& Spivak, 1999; Invernizzi, Zefferino, Santos, Sánchez, \& Mendoza, 2015).

The other influence that grooming can have on colony health and disease resistance is through social immunization. Exposure to and grooming of sick individuals in some cases can lead to increased survival upon subsequent pathogen challenge (Konrad et al., 2012; Traniello, Rosengaus, \& Savoie, 2002). Because social insects do not have antibodies, as is seen in vertebrates, the mechanism appears to be that low-level exposures can either prime the immune system to better fight off subsequent exposures (Konrad et al., 2012) or allow the exchange of antimicrobials (Hamilton et al., 2011). Furthermore studies in leaf-cutting ants suggest that allogrooming is an inducible response that increases based on nestmate exposure to parasites (Walker \& Hughes, 2009). An additional mechanism that has just recently been explored is the concept of "trans-generational immune priming," whereby exposures of the queen to non-pathogenic or heat-killed bacteria can lead to increased immune response and subsequent survival of her offspring when they are challenged (Lopez, Schuehly, Crailsheim, \& RiessbergerGalle, 2014; Salmela, Amdam, \& Freitak, 2015).

While the social immunization hypothesis has yet to be explicitly tested in honey bee workers there is some evidence from experiments that examined the responses of healthy bees to immune-challenged bees, where bees that were injected with a bacteria received more allo-grooming than non-injected bees (Richard, Holt, \& Grozinger, 2012). This suggests that bees can detect individuals that have an activated immune system. The fact that immune-challenged bees received more grooming interactions warrants further study of the impacts that this may have on disease transmission and resistance.
Additionally the potential costs of this behaviour need to be explored more fully as models incorporating self-grooming, allo-grooming and various pathogens indicate grooming can both reduce and increase disease risk depending on the pathogenicity of the study organisms (Novak \& Cremer, 2015; Theis, Ugelvig, Marr, \& Cremer, 2015).

\section{Hygienic Behavior}

Hygienic behavior-the detection and removal of infected brood-is the quintessential example of a mechanism of social immunity (Evans \& Spivak, 2010; Spivak \& Gilliam, 1998a,1998b). In colonies that exhibit rapid hygienic behavior, adult bees detect diseased or parasitized larvae and pupae before they reach the infectious stage. The larva or pupa is removed from the colony along with the pathogen or parasite, which reduces the spread of that infection through the colony. This typifies social immunity because that individual larva or pupa is not saved from infection, but it is removed before full symptom development to prevent the transmission of that disease throughout the colony.

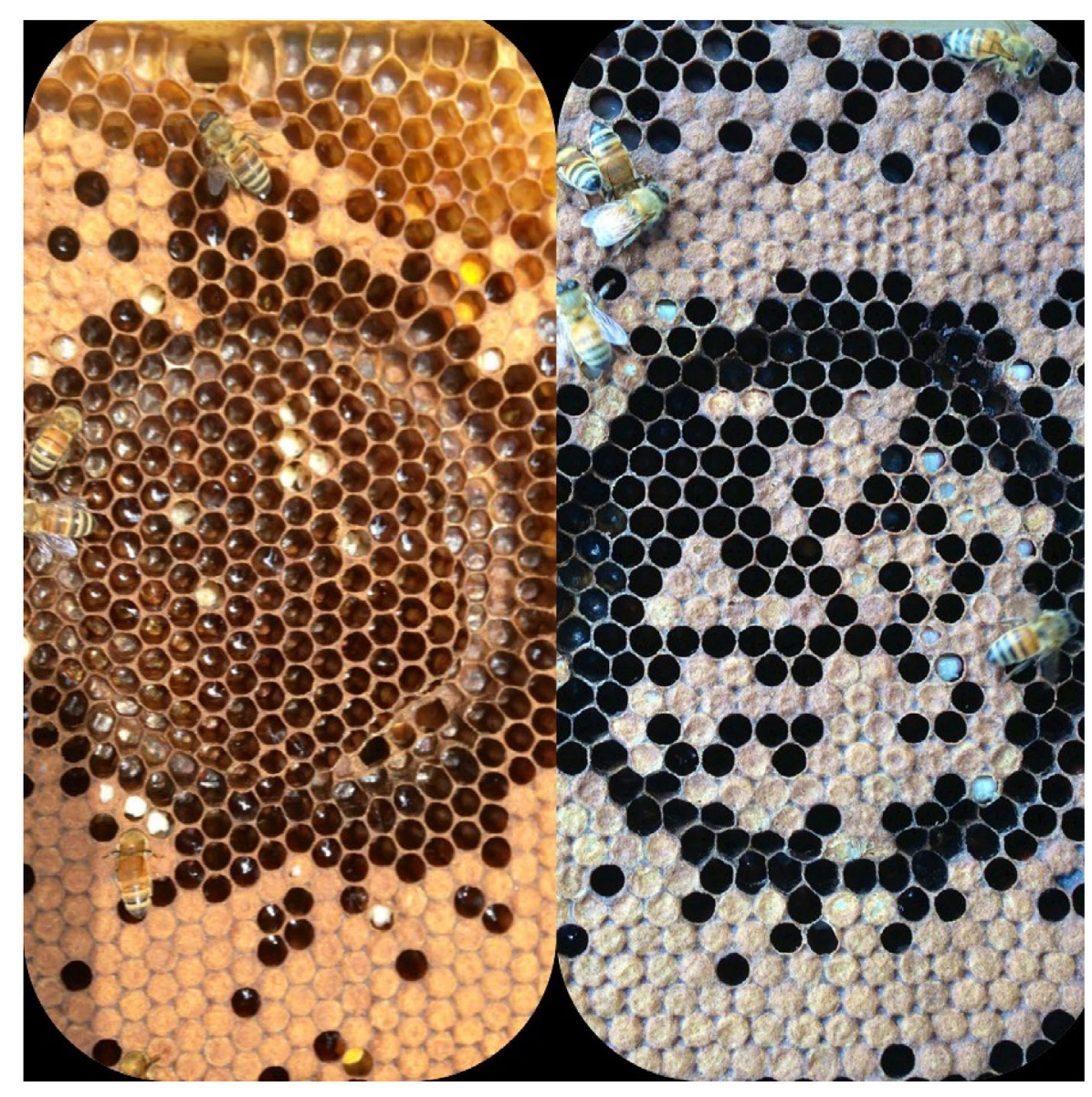

$\triangle$ Figure 4. Hygienic behaviour assay. Cells within the circles were frozen to kill pupae. After $24 \mathrm{~h}$, some colonies completely remove the freeze-killed brood and are deemed rapidly hygienic (left), while other poorly hygienic colonies remove some dead pupae, uncap and partially remove others, but leave more capped (right).

Photos by $M$. Simone-Finstrom. 
Thus hygienic behavior is not directly protecting sick individuals but rather is having effects at the colony level.

Hygienic behavior is easily assessed using the freeze-killed brood assay, where a section of brood is frozen using liquid nitrogen and the removal of these dead pupae after $24 \mathrm{~h}$ is determined (Figure 4) (Spivak \& Reuter, 1998; Wilson-Rich, Spivak, Fefferman, \& Starks, 2009). There are three major stages of this behavior: (1) detection, (2) uncapping and (3) removal (Arathi, Burns, \& Spivak, 2000). Some colonies express only one or two of these components of the behavioral process (for example, in poorly-hygienic colonies bees often recap cells with diseased pupae), so the suite of behaviors is required for full effect. While the uncapping and removal is highly induced by the presence of parasites and pathogens, inspection behavior constantly occurs (Arathi, Ho, \& Spivak, 2006). Colonies express a continuum of this trait with some colonies performing almost no hygienic behavior and others detecting and removing all of the dead pupae in less than 24 h (Spivak \& Downey, 1998). Hygienic behavior appears to exist in all races of $A$. mellifera and so would seem to offer high potential for improvement by selection across different beekeeping operations (Spivak \& Gilliam, 1998a). Rate of removal of freeze-killed brood is correlated with colony-level resistance to the bacterial disease American foulbrood and the fungal disease chalkbrood (Spivak \& Gilliam, 1998a; Spivak \& Reuter, 2001a). However selection based on this assay alone only confers partial resistance to the parasitic mite $V$. destructor (Ibrahim, Reuter, \& Spivak, 2007; Ibrahim \& Spivak, 2006; Spivak \& Reuter, 2001b), though this level of resistance can reduce effects of the mite-vectored Deformed wing virus (Toufailia, Amiri, Scandian, Kryger, \& Ratnieks, 2014).

Varroa Sensitive Hygiene (VSH) is a trait that has been under selection as part of a breeding program since the mid1990s (Danka, Harris, \& Dodds, 2016; Harbo \& Harris, 2005). One focus of this selection program has been specifically determining the proportion of miteinfested pupae that are removed. This is a much more time-intensive assay than the freeze-kill brood method, but colonies with a high expression of VSH exhibit low mite population growth over a season (Harbo \& Harris, 2001; Ward, Danka, \& Ward, 2008). Colonies bred through the VSH selection process remove freeze-killed brood at a comparable rate to colonies from lines bred based on the freeze-killed brood assay (Danka,
Harris, Villa, \& Dodds, 2013). While it has not yet been tested whether or not VSH bees are similarly resistant to American foulbrood and chalkbrood, one current hypothesis is that VSH-selected colonies simply have a lower threshold of detection for parasitized brood potentially in addition to other mechanisms that confer resistance (Ibrahim \& Spivak, 2006). Like the more general hygienic behavior assayed with the freeze-kill test, VSH behavior can be found globally across different races and stocks of $A$. mellifera (Büchler, Berg, \& Le Conte, 2010; Le Conte et al., 2011; Mondet et al., 2016), and has been noted as one of the mechanisms explaining Varroa resistance in Russian honey bees (Kirrane et al., 2015).

One other potential aspect of hygienic behavior is the removal of sick or parasitized adult honey bees. Both current methods to assess hygienic behavior involve analyzing brood removal. Perhaps removal of sick adults is modulated by a similar process. Sick individuals are known to remove themselves from the colony, or rather fail to return to the colony (Rueppell, Hayworth, \& Ross, 2010), but symptomatic adult bees are also actively removed (Baracchi, Fadda, \& Turillazzi, 2012). One potential is that bees performing hygienic behavior are able to detect cuticular hydrocarbon changes (Richard, Aubert, \& Grozinger, 2008; Salvy et al., 2001) or other chemical signals produced by parasitized individuals (Mondet et al., 2016; Schoning et al., 2012; Swanson et al., 2009) that stimulates removal. This mechanism could potentially explain effects for larval, pupal and adult removal.

\section{Highly Induced Colony Responses: Social Fever and Absconding}

Honey bee colonies have been shown to increase the brood nest temperature slightly to inhibit the development of chalkbrood symptoms in infected larvae (Starks, Blackie, \& Seeley, 2000). This "social fever" response appears to only be induced by the presence of chalkbrood fungal spores, which can be sensitive to temperature changes. The fever response however is complex and likely influenced by other environmental conditions (Simone-Finstrom et al., 2014; Starks et al., 2000). The consistency and heritability of this behaviour and its potential response to other pathogens and parasites should be investigated further, particularly as there is interest in a colony's ability to properly and consistently thermoregulate the nest (Jones, Myerscough, Graham, \& Oldroyd, 2004; Simone-Finstrom et al., 2014).

While colony-level infection can cause honey bees to initiate behaviors to remove the disease from the nest (e.g., fever, hygienic behavior, resin collection), the other strategy is to leave the nest behind and restart in a new, disease-free hive. Absconding occurs when an entire colony leaves the nest and any brood or food stores behind to find a new nest cavity. Absconding is a more common trait in Africanized and some Asian honey bees, it does occur in the European honey bee as well and can be induced with high levels of pathogens, parasites or pests (Ellis, Hepburn, Delaplane, \& Elzen, 2003; Winston, Taylor, \& Otis, 1983). There is evidence that this can have effects on the spread of disease, at least within a colony, and some management practices to deal with certain diseases (e.g., American foulbrood) basically mimic the absconding behavior (Fries \& Raina, 2003). However, while there is likely a genetic predisposition to abscond, this is not a trait that would be beneficial for selection under current beekeeping management practices.

\section{Conclusions}

Honey bees are truly impressive creatures both when considered at the individual bee level and also how they operate as a superorganism when the colony is considered as the "individual." Despite all of the stressors that bees face from pathogens, parasites, pesticides and management, honey bees are resilient and have numerous traits to combat these near constant threats. As researchers, bee breeders and bee wranglers, our goal should be to support these natural defenses to make bees stronger on their own. Breeding efforts that focus not just on one resistance trait but involve multi-trait selection for productivity and resistance traits (e.g., hygienic behavior, grooming, propolis collection) should be at the forefront. Developing methods to quickly and effectively evaluate colonies for these various traits is an important step to advance the field.

\section{References}

Adam, G.H., \& Francis, L.W.R. (200I).Task partitioning, division of labour and nest compartmentalisation collectively isolate hazardous waste in the leafcutting ant Atta cephalotes. Behavioral Ecology and Sociobiology, 49, 387-392.

Adamo, S.A., Davies, G., Easy, R., Kovalko, I., \& Turnbull, K.F. (2016). Reconfiguration of the immune system network during 
food limitation in the caterpillar Manduca sexta. Journal of Experimental Biology, 219, 706-718. doi: 10.1242/jeb. 132936

Antúnez, K., Harriet, J., Gende, L., Maggi, M., Eguaras, M., \& Zunino, P. (2008). Efficacy of natural propolis extract in the control of American Foulbrood. Veterinary Microbiology, 131 , 324-331. doi: I0. I0 I6/j.vetmic.2008.04.0 I

Arathi, H.S., Burns, I., \& Spivak, M. (2000). Ethology of hygienic behaviour in the honey bee Apis mellifera L. (Hymenoptera: Apidae): Behavioural repertoire of hygienic bees. Ethology, 106 365-379. doi: I0.1046/j. I 439-0310.2000.00556.x

Arathi, H.S., Ho, G., \& Spivak, M. (2006). Inefficient task partitioning among nonhygienic honeybees, Apis mellifera L, and implications for disease transmission. Animal Behaviour, 72, 431-438. doi: 10.1016/j.anbehav.2006.01.018

Arechavaleta-Velasco, M.E., Alcala-Escamilla, K., Robles-Rios, C., Tsuruda, J.M., \& Hunt, G.J. (20 I 2). Fine-scale linkage mapping reveals a small set of candidate genes influencing honey bee grooming behavior in response to varroa mites. PLoS One, 7, e47269. doi:10.137|/journal.pone.0047269.

Bailey, L. (1999). The quest for a super-bee. Bee World, 80, 55-60. doi: 10.1080/0005772X.1999.1 1099427

Bankova, V., \& Marcucci, M.C. (2000). Standardization of propolis: Present status and perspectives. Bee World, 81, | 82-| 88. doi: | 0. I 080/0005772X.2000. I 1099492

Bankova, V.S., de Castro, S.L., \& Marcucci, M.C. (2000). Propolis: Recent advances in chemistry and plant origin. Apidologie, 31, 3-15.

Baracchi, D., \& Cini, A. (20/4). A socio-spatial combined approach confirms a highly compartmentalised structure in honeybees. Ethology, 120, | |67-1 176. doi: 10.1111/1 eth. 12290

Baracchi, D., Fadda, A., \& Turillazzi, S. (20।2). Evidence for antiseptic behaviour towards sick adult bees in honey bee colonies. Journal of Insect Physiology, 58, I 589-1596. doi: 10.1016/j.jinsphys.2012.09.014

Baracchi, D., Francese, S., \& Turillazzi, S. (201 I). Beyond the antipredatory defence: Honey bee venom function as a component of social immunity. Toxicon, 58, 550-557. doi: | 0.1016/j.toxicon.201 1.08.017

Baracchi, D., Mazza, G., \& Turillazzi, S. (20।2). From individual to collective immunity: The role of the venom as antimicrobial agent in the Stenogastrinae wasp societies. Journal of Insect Physiology, 58, 188-193. doi:10.1016/j. jinsphys.2011.11.007

Barribeau, S.M., Sadd, B.M., du Plessis, L., Brown, M.J.F., Buechel, S.D., Cappelle, K., \& Schmid-Hempel, P. (20I5). A depauperate immune repertoire precedes evolution of sociality in bees. Genome Biology, 16, 20. doi: I0.1 186/ s|3059-0|5-0628-y

Boecking, O., \& Spivak, M. (1999). Behavioral defenses of honey bees against Varroa jacobsoni Oud. Apidologie, 30 , |4 |-|58. doi: | 0. I05 |/apido: 19990205

Borba, R.S. (2015). Constitutive and therapeutic benefits of plant resins and a propolis envelope to honey bee, Apis mellifera L., immunity and health (37348I2 Ph.D.), University of Minnesota, Ann Arbor:

Borba, R.S., Klyczek, K.K., Mogen, K.L., \& Spivak, M. (20I5) Seasonal benefits of a natural propolis envelope to honey bee immunity and colony health. Journal of Experimental Biology, 2 18, 3689-3699. doi: 10.1242/jeb. 127324

Bot, A.N.M., Currie, C.R., Hart, A.G., \& Boomsma, I.J. (200 I) Waste management in leaf-cutting ants. Ethology Ecology \& Evolution, 13, 225-237. doi: 10.1080/08927014.2001.95 22772

Büchler, R., Berg, S., \& Le Conte,Y. (20 I0). Breeding for resistance to Varroa destructor in Europe. Apidologie, 4I, 393-408. doi: |0. 105 |/apido/20 1001

Cotter, S.C., \& Kilner, R.M. (20I0). Personal immunity versus social immunity. Behavioral Ecology, 21, 663-668. doi: 1 0. 1093/beheco/arq070
Cremer, S., Armitage, S.A.O., \& Schmid-Hempel, P. (2007). Social immunity. Current Biology, 17, R693-R702 doi: | 0.10 | 6/j.cub.2007.06.008

Cremer, S., \& Sixt, M. (2009). Analogies in the evolution of individual and social immunity. Philosophical Transactions of the Royal Society B: Biological Sciences, 364, 129-142.

Danka, R.G., Harris, J.W., \& Dodds, G.E. (20।6). Selection of VSH-derived "Pol-line" honey bees and evaluation of their Varroa-resistance characteristics. Apidologie, 47, 483-490. doi: | 0. I 007/s | 3592-015-04 |3-7

Danka, R.G., Harris, J.W., Villa, J.D., \& Dodds, G.E. (20।3) Varying congruence of hygienic responses to Varroa destructor and freeze-killed brood among different types of honeybees. Apidologie, 44, 447-457. doi: 10. I007/s | 3592-013-0195-8

Danka, R.G., \& Villa, J.D. ( 1998). Evidence of autogrooming as a mechanism of honey bee resistance to tracheal mite infestation. Journal of A picultural Research, 37, 39-46. doi: 10.1 080/00218839.1998.1|100953

Drescher, N., Klein, A.M., Neumann, P., Yañez, O., \& Leonhardt, S. (2017). Inside honeybee hives: Impact of natural propolis on the ectoparasitic mite Varroa destructor and viruses. Insects, 8, I5.

Eckholm, B.J., Anderson, K.E.,Weiss, M., \& DeGrandiHoffman, G. (20I I). Intracolonial genetic diversity in honeybee (Apis mellifera) colonies increases pollen foraging efficiency. Behavioral Ecology and Sociobiology, 65, 1037-1044. doi: | 0. I 007/s00265-0 | 0- | | 08-8

Ellis, J.D., Hepburn, H.R., Ellis, A.M., \& Elzen, P.J. (2003). Social encapsulation of the small hive beetle (Aethina tumida Murray) by European honeybees (Apis mellifera L.). Insectes Sociaux, 50, 286-291. doi: 10.1007/s00040-003-067।-7

Ellis, J.D., Hepburn, R., Delaplane, K.S., \& Elzen, P.). (2003). A scientific note on small hive beetle (Aethina tumida) oviposition and behaviour during European (Apis mellifera) honey bee clustering and absconding events. Journal of Apicultural Research, 42,47-48. doi: $10.1080 / 002$ I 8839.2003.1 I I01089

Erler, S., Denner, A., Bobiş, O., Forsgren, E., \& Moritz, R.F.A. (2014). Diversity of honey stores and their impact on pathogenic bacteria of the honeybee, Apis mellifera. Ecology and Evolution, 4, 3960-3967. doi: I0.1002/ece3.1252

Erler, S., \& Moritz, R.F. (2016). Pharmacophagy and pharmacophory: Mechanisms of self-medication and disease prevention in the honeybee colony (Apis mellifera). Apidologie, 47, 389-4II.

Evans, J.D., Aronstein, K., Chen, Y.P., Hetru, C., Imler, J.L., Jiang H., ... Hultmark, D. (2006). Immune pathways and defence mechanisms in honey bees Apis mellifera. Insect Molecular Biology, 1 5, 645-656. doi: I 0. I | | | /j. I 365-2583.2006.00682.x

Evans, J.D., \& Pettis, J.S. (2005). Colony-level impacts of immune responsiveness in honey bees. Apis mellifera. Evolution, 59, 2270-2274. doi: I0. I554/05-060.

Evans, J.D., \& Spivak, M. (20।0). Socialized medicine: Individual and communal disease barriers in honey bees. Journal of Invertebrate Pathology, 103, S62-S72. doi: $10.1016 / j$. jip.2009.06.019

Evison, S.E.F., Fazio, G., Chappell, P., Foley, K., Jensen, A.B., \& Hughes, W.O.H. (20 I3). Host-parasite genotypic interactions in the honey bee:The dynamics of diversity. Ecology and Evolution, 3, 2214-2222. doi: 10.1002/ece3.599

Fearnley, J. (200 I). Bee propolis: Natural healing from the hive: Souvenir.

Fefferman, N.H., \& Traniello, J.F.A. (2008). Social insects as models in epidemiology: Establishing the foundation for an interdisciplinary approach to disease and sociality. In I. Gadau, \& J.H. Fewell (Eds.), Organization of insect societies: From genome to sociocomplexity. Cambridge, MA: Harvard University Press.

Fries, l., \& Raina, S. (2003). American foulbrood and African honey bees (Hymenoptera: Apidae). Journal of Economic Entomology, 96, I 64 I-1646. doi: I0.1603/0022-049396.6.1641
Gadau, .., Helmkampf, M., Nygaard, S., Roux, J., Simola, D.F. Smith, C.R., ... Smith, C.D. (20।2). The genomic impact of 100 million years of social evolution in seven ant species. Trends in Genetics, 28, |4-2|.

Gherman, B.ı., Denner, A., Bobiş, O., Dezmirean, D.S., Mărghitaş, L.A., Schlüns, H., ... Erler, S. (20|4). Pathogenassociated self-medication behavior in the honeybee Apis mellifera. Behavioral Ecology and Sociobiology, 68, 1777-1784. doi: | 0.1007/s00265-0|4-|786-8

Ghisalberti, E.L. (1979). Propolis: A review. Bee World, 60, 59-84. doi: I0.1080/0005772x.1979.1 1097738

Hamilton, C., Lejeune, B.T., \& Rosengaus, R.B. (20I I). Trophallaxis and prophylaxis: Social immunity in the carpenter ant Camponotus pennsylvanicus. Biology Letters, 7 , 89-92. doi: | 0.1098/rsbl.2010.0466

Hamilton, R., Siva-Jothy, M., \& Boots, M. (2008). Two arms are better than one: Parasite variation leads to combined inducible and constitutive innate immune responses. Proceedings of the Royal Society B: Biological Sciences, 275, 937-945. doi: I0.1098/rspb.2007. 1574

Harbo, J.R., \& Harris, J.W. (200 I). Resistance to Varro destructor (Mesostigmata:Varroidae) when mite-resistant queen honey bees (Hymenoptera: Apidae) were free-mated with unselected drones. Journal of Economic Entomology, 94 | 319-1323. doi: | 0.1 603/0022-0493-94.6. 1319

Harbo, J.R., \& Harris, J.W. (2005). Suppressed mite reproduction explained by the behaviour of adult bees. Journal of Apicultural Research, 44, 21-23. doi: 10.1080/00218 839.2005. | | | $01|4|$

Harpur, B.A., \& Zayed, A. (20I3). accelerated evolution of innate immunity proteins in social insects: Adaptive evolution or relaxed constraint? Molecular Biology and Evolution, 30, | 665-| 674. doi: | 0.1093/molbev/mst06 |

Ibrahim, A., Reuter, G.S., \& Spivak, M. (2007). Field trial of honey bee colonies bred for mechanisms of resistance against Varroa destructor. Apidologie, 38, 67-76. doi: 10. 105 I/ apido:2006065

Ibrahim, A., \& Spivak, M. (2006). The relationship between hygienic behavior and suppression of mite reproduction as honey bee (Apis mellifera) mechanisms of resistance to Varroa destructor. Apidologie, 37, 31-40. doi: 10.1051/ apido:2005052

Invernizzi, C., Penagaricano, F., \& Tomasco, I.H. (2009). Intracolonial genetic variability in honeybee larval resistance to the chalkbrood and American foulbrood parasites. Insectes Sociaux, 56, 233-240. doi: 10.1007/s00040-009 $0016-2$

Invernizzi, C., Zefferino, l., Santos, E., Sánchez, L., \& Mendoza Y. (20I5). Multilevel assessment of grooming behavior against Varroa destructor in Italian and Africanized honey bees. Journal of Apicultural Research, 54, 321-327. doi: 10.108 $0 / 00218839.2016 .1159055$

Johnson, B.R. (2010). Division of labor in honeybees: Form, function, and proximate mechanisms. Behavioral Ecology and Sociobiology, 64, 305-3 | 6. doi: 10.1007/s00265-009-0874-7

Jones, J.C., Myerscough, M.R., Graham, S., \& Oldroyd, B.P. (2004). Honey bee nest thermoregulation: Diversity promotes stability. Science, 305, 402-404. doi: I 0. I | 26/ science. 1096340

Kirrane, M.J., de Guzman, L.I., Holloway, B., Frake, A.M. Rinderer,T.E., \& Whelan, P.M. (20I5). Phenotypic and genetic analyses of the varroa sensitive hygienic trait in russian honey bee (Hymenoptera:Apidae) colonies. PLoS One, 10 e0 | | 6672. doi: | 0. I 37|/journal.pone.01 |6672

Klaudiny, J., Albert, Š., Bachanová, K., Kopernický, J., \& Šimúth, J. (2005). Two structurally different defensin genes, one of them encoding a novel defensin isoform, are expressed in honeybee Apis mellifera. Insect Biochemistry and Molecular Biology, 35, I |-22. doi: I 0. I 0 | 6/i.ibmb.2004.09.007

Koch, H., \& Schmid-Hempel, P. (20I I). Socially transmitted gut microbiota protect bumble bees against an intestinal 
parasite. Proceedings of the National Academy of Sciences, 108, 19288-19292. doi: 10.1073/pnas. I I 10474108

Konrad, M.,Vyleta, M.L., Theis, F..., Stock, M., Tragust, S., Klatt, M., \& Cremer, S. (20I2). Social transfer of pathogenic fungus promotes active immunisation in ant colonies. Plos Biology, I0, e I00 I 300. doi: I0.137|/journal.pbio. I00 I 300

Langenheim, J.H. (2003). Plant resins: Chemistry, evolution, ecology and ethnobiology. Portland, OR:Timber Press.

Le Conte, Y., Alaux, C., Martin, J.F., Harbo, J.R., Harris, J.W., Dantec, C., \& Navajas, M. (20I I). Social immunity in honeybees (Apis mellifera): Transcriptome analysis of varroahygienic behaviour. Insect Molecular Biology, 20, 399-408. doi:10.1 I | |/j.1365-2583.2011.01074.x

Lee, G.M., McGee, P.A., \& Oldroyd, B.P. (20I3).Variable virulence among isolates of Ascosphaera apis:Testing the parasite-pathogen hypothesis for the evolution of polyandry in social insects. Naturwissenschaften, 100, 229-234. doi: | 0.1007/s00 | |4-0|3-10 |6-7

Lindenfelser, L.A. (1968). In vivo activity of propolis against Bacillus larvae. Journal of Invertebrate Pathology, |2, |29-|3|. doi: | 0. I 0 1 6/0022-20 I I (68)90252-8

López-Uribe, M.M., Appler, R.H., Youngsteadt, E., Dunn, R.R., Frank, S.D., \& Tarpy, D.R. (20।7). Higher immunocompetence is associated with higher genetic diversity in feral honey bee colonies (Apis mellifera). Conservation Genetics, I-8. doi: | 0. I007/s | 0592-017-0942-x

López-Uribe, M.M., \& Simone-Finstrom, M. (2017). Glucose oxidase production does not increase after colony infection: Testing its role in honey bee social immunity. In M. SimoneFinstrom (Ed.), Proceedings of the 2017 American Bee Research Conference (Vol. 93, pp. 104-127): Bee World doi: | 0.1080/0005772X.20|17.|29447|

Lopez, J.H., Schuehly, W., Crailsheim, K., \& Riessberger-Galle, $\cup .(20 \mid 4)$. Trans-generational immune priming in honeybees. Proceedings of the Royal Society B-Biological Sciences, 28I, 20 | 40454. doi: | 0. I 098/rspb.20 | 4.0454

Mattila, H.R., Rios, D., Walker-Sperling, V.E., Roeselers, G. \& Newton, I.L.G. (20I2). Characterization of the active microbiotas associated with honey bees reveals healthier and broader communities when colonies are genetically diverse. PLoS One, 7. e32962. doi: |0.137|/journal. pone.0032962

Mattila, H.R., \& Seeley,T.D. (2007). Genetic diversity in honey bee colonies enhances productivity and fitness. Science, 317 , 362-364. doi: 10.1 | 26/science. I | 43046

Meunier,. (20I5). Social immunity and the evolution of group living in insects. Philosophical Transactions of the Royal Society B-Biological Sciences, 370, I0. doi: 10.1098/rstb.2014.0102

Mirabito, D., \& Rosengaus, R.B. (2016). A double-edged sword? The cost of proctodeal trophallaxis in termites. Insectes Sociaux, 63, I35-|41. doi: 10.1007/s00040-0I5 0448- 9

Mondet, F., Kim, S.H., de Miranda, J.R., Beslay, D., Le Conte.Y., \& Mercer,A.R. (20।6). Specific cues associated with honey bee social defence against Varroa destructor infested brood. Scientific Reports, 6, 25444. doi: I0.1 038/srep25444http://www.nature. com/articles/srep25444\#supplementary-information

Moreau, S.J.M. (2013). "It stings a bit but it cleans well:" Venoms of hymenoptera and their antimicrobial potential. Journal of Insect Physiology, 59, 186-204. doi: 10.1016/j. jinsphys.20I2.10.005

Naug, D. (2008). Structure of the social network and its influence on transmission dynamics in a honeybee colony. Behavioral Ecology and Sociobiology, 62, 1719-1725. doi: 10.1 007/s00265-008-0600-x

Naug, D., \& Camazine, S. (2002). The role of colony organization on pathogen transmission in social insects. Journal of Theoretical Biology, 2 1 5, 427-439. doi: 1 0.1 006/jtbi.200 I.2524

Neumann, P., Pirk, C., Hepburn, H., Solbrig, A., Ratnieks, F. Elzen, P., \& Baxter, J. (200 I). Social encapsulation of beetle parasites by Cape honeybee colonies (Apis mellifera capensis Esch.). Naturwissenschaften, 88, 214-216. doi: 10.1007/s00 | | 4010022

Nicodemo, D., Malheiros, E.B., De Jong, D., \& Couto, R.H.N. (20I4). Increased brood viability and longer lifespan of honeybees selected for propolis production. Apidologie, 45 269-275. doi: | 0. I 007/s | 3592-0 I3-0249-y

Novak, S., \& Cremer, S. (20I5). Fungal disease dynamics in insect societies: Optimal killing rates and the ambivalent effect of high social interaction rates. Journal of Theoretical Biology, 372, 54-64. doi: 10.1016/j.jtbi.2015.02.018

Ohashi, K., Natori, S., \& Kubo,T. (1999). Expression of amylase and glucose oxidase in the hypopharyngeal gland with an age-dependent role change of the worker honeybee (Apis mellifera L.). European Journal of Biochemistry, 265, I27-| 33. doi: I0.1046/j. I 432- | 327. $1999.00696 . x$

Otti, O., Tragust, S., \& Feldhaar, H. (20 | 4). Unifying external and internal immune defences. Trends in Ecology \& Evolution, 29. 625-634. doi: | 0.10 | 6/j.tree.2014.09.002

Palmer, K.A., \& Oldroyd, B.P. (2000). Evolution of multiple mating in the genus Apis. Apidologie, 31, 235-248.

Palmer, K.A., \& Oldroyd, B.P. (2003). Evidence for intracolonial genetic variance in resistance to American foulbrood of honey bees (Apis mellifera): Further support for the parasite/pathogen hypothesis for the evolution of polyandry. Naturwissenschaften, 90, 265-268. doi:|0.1007/s00 | |4-003-04|8-3

Pettis, I.S., \& Pankiw, T. (1998). Grooming behavior by Apis mellifera L. in the presence of Acarapis woodi (Rennie) (Acari: Tarsonemidae). Apidologie, 29, 24I-253

Popova, M., Reyes, M., Le Conte,Y., \& Bankova,V. (20।4). Propolis chemical composition and honeybee resistance against Varroa destructor. Natural Product Research, 28,788-794.

Powell, J.E., Martinson, V.G., Urban-Mead, K., \& Moran, N.A. (20।4). Routes of acquisition of the gut microbiota of the honey bee Apis mellifera. Applied and Environmental Microbiology, 80,7378-7387. doi:I0.1 | 28/aem.01861-14

Rangel, J., Keller, J.J., \& Tarpy, D.R. (20।3). The effects of honey bee (Apis mellifera L.) queen reproductive potential on colony growth. Insectes Sociaux, 60, 65-73. doi: $10.1007 /$ s00040-0 I 2-0267-1

Richard, F.J., Aubert, A., \& Grozinger, C.M. (2008). Modulation of social interactions by immune stimulation in honey bee, Apis mellifera, workers. BMC Biology, 6, 50. doi: 10.1 186/17417007-6-50

Richard, F.J., Holt, H.L., \& Grozinger, C.M. (20I2). Effects of immunostimulation on social behavior, chemical communication and genome-wide gene expression in honey bee workers (Apis mellifera). Bmc Genomics, 13, 558 doi: 10.1 | 86/|47|-2164-13-558

Rose, R.I., \& Briggs, J.D. (1969). Resistance to American foulbrood in honey bees IX. Effects of honey-bee larval food on the growth and viability of Bacillus larvae. Journal of Invertebrate Pathology, 13, 74-80. doi: 10.1016/0022 201 I (69)90240-7

Rueppell, O., Hayworth, M.K., \& Ross, N.P. (20 I0). Altruistic self-removal of health-compromised honey bee workers from their hive. Journal of Evolutionary Biology, 23, 1538| 546. doi: | 0.1 | | |/j. |420-9 |01.2010.02022.x

Rueppell, O., Linford, R., Gardner, P., Coleman, J., \& Fine, K (2008). Aging and demographic plasticity in response to experimental age structures in honeybees (Apis mellifer L). Behavioral Ecology and Sociobiology, 62, |621-1631. doi: | 0. 1007/s00265-008-059|-7

Ruttner, F. (1956). The mating of the honey bee. Bee World, 37. 3-5. doi: 10.1080/0005772X.1956.1 10949|3

Salmela, H., Amdam, G.V., \& Freitak, D. (2015). Transfer of immunity from mother to offspring is mediated via eggyolk protein vitellogenin. PLoS Pathogens, / I, el 005015. doi: 10.137 |/journal.ppat. 1005015

Salvy, M., Martin, C., Bagneres, A., Provost, E., Roux, M., Le Conte, Y., \& Clement, J. (200I). Modifications of the cuticular hydrocarbon profile of Apis mellifera worker bees in the presence of the ectoparasitic mite Varroa jacobsoni in brood cells. Parasitology, 122, |45-159.

Schoning, C., Gisder, S., Geiselhardt, S., Kretschmann, I., Bienefeld, K., Hilker, M., \& Genersch, E. (20I2). Evidence for damage-dependent hygienic behaviour towards Varroa destructor-parasitised brood in the western honey bee, Apis mellifera. The Journal of Experimental Biology, 215, 264-27l. doi: 10.1242/jeb.062562

Seeley, T.D. (1997). Honey bee colonies are group-level adaptive units. The American Naturalist, 150, S22-S4I. doi: $10.1086 / 286048$

Seeley,T.D., \& Morse, R.A. (1976). Nest of the honey bee (Apis mellifera L.). Insectes Sociaux, 23, 495-5 I2. doi: I0.1007/ bf02223477

Sforcin, J.M., \& Bankova, V. (20 I I). Propolis: Is there a potential for the development of new drugs? Journa of Ethnopharmacology, 133, 253-260. doi: I 0. I0 | 6/j. jep.2010.10.032

Silva-Carvalho, R., Baltazar, F., \& Almeida-Aguiar, C. (2015). Propolis: A complex natural product with a plethora of biological activities that can be explored for drug development. Evidence-Based Complementary and Alternative Medicine, 20/5, I-29. doi: I0.1155/2015/206439

Simola, D.F., Wissler, L., Donahue, G., Waterhouse, R.M. Helmkampf, M., Roux, .., ... Viljakainen, L. (2013). Social insect genomes exhibit dramatic evolution in gene composition and regulation while preserving regulatory features linked to sociality. Genome Research, 23, 1235-1247.

Simone-Finstrom, M., Foo, B., Tarpy, D.R., \& Starks, P.T. (2014). Impact of food availability, pathogen exposure, and genetic diversity on thermoregulation in honey bees (Apis mellifera). Journal of Insect Behavior, 27, 527-539. doi: I 0. I 007/s I0905 014-9447-3

Simone-Finstrom, M., \& Spivak, M. (20।0). Propolis and bee health:The natural history and significance of resin use by honey bees. Apidologie, 41, 295-311. doi:10.1051/ apido/2010016

Simone-Finstrom, M.D., \& Spivak, M. (20I2). Increased resin collection after parasite challenge: $A$ case of self-medication in honey bees? PLoS One, 7.7. doi: 10.137|/journal.pone.003460

Simone-Finstrom, M., Walz, M., \& Tarpy, D.R. (20 I 6). Genetic diversity confers colony-level benefits due to individual immunity. Biology Letters, 12, 20151007 . doi: 10.1098/ rsbl.2015.1007

Simone, M., Evans, J.D., \& Spivak, M. (2009). Resin collection and social immunity in honey bees. Evolution, 63, 3016-3022. doi: | 0.1 | | | /j. 1558-5646.2009.00772.x

Spivak, M., \& Downey, D.L. (1998). Field assays for hygienic behavior in honey bees (Hymenoptera: Apidae). Journal of Economic Entomology, 91, 64-70

Spivak, M., \& Gilliam, M. (1998a). Hygienic behaviour of honey bees and its application for control of brood diseases and Varroa - Part I. Hygienic behaviour and resistance to American foulbrood. Bee World, 79, 124-134. doi: I 0. 1 080/0 $005772 \times 1998.11099394$

Spivak, M., \& Gilliam, M. (1998b). Hygienic behaviour of honey bees and its application for control of brood diseases and varroa - Part II. Studies on hygienic behaviour since the Rothenbuhler era. Bee World, 79, I69-I86. doi: I 0. I080/000 $5772 \times .1998 .11099408$

Spivak, M., \& Reuter, G.S. (1998). Performance of hygienic honey bee colonies in a commercial apiary. Apidologie, 29, 29|-302. doi: | 0.1 05 |/apido: 19980308

Spivak, M., \& Reuter, G.S. (200 I a). Resistance to American foulbrood disease by honey bee colonies (Apis mellifera) bred for hygienic behavior. Apidologie, 32, 555-565.

Spivak, M., \& Reuter, G.S. (200 I b). Varroa destructor infestation in untreated honey bee (Hymenoptera: Apidae) colonies selected for hygienic behavior Journal of Economic Entomology, 94, 326-331. doi: 1 0. I 603/0022-0493-94.2.326 
Starks, P.T., Blackie, C.A., \& Seeley,T.D. (2000). Fever in honeybee colonies. Naturwissenschaften, 87, 229-231. doi: | 0.1 007/s00 | | 40050709

Stow, A., Briscoe, D., Gillings, M., Holley, M., Smith, S., Leys, R Beattie, A. (2007). Antimicrobial defences increase with sociality in bees. Biology Letters, 3, 422-424. doi: 10. I098/rsbl.2007.0 178

Sugahara, M., \& Sakamoto, F. (2009). Heat and carbon dioxide generated by honeybees jointly act to kill hornets. Naturwissenschaften, 96, | |33-| | 36. doi: | 0.1007/s00 | |4009-0575-0

Swanson, J.A.l., Torto, B., Kells, S.A., Mesce, K.A., Tumlinson, J.H., \& Spivak, M. (2009). Odorants that induce hygienic behavior in honeybees: Identification of volatile compounds in chalkbrood-infected honeybee larvae. Journal of Chemical Ecology, 35, I I08-1 | | 6. doi: I 0. I 007/s I 0886-009-9683-8

Tarpy, D.R. (2003). Genetic diversity within honeybee colonies prevents severe infections and promotes colony growth. Proceedings of the Royal Society of London Series B-Biological Sciences, 270, 99-103. doi: 10.1098/rspb.2002.2199

Tarpy, D.R., Hatch, S., \& Fletcher, D.J.C. (2000). The influence of queen age and quality during queen replacement in honeybee colonies. Animal Behaviour, 59, 97-101. doi: 10.1006/anbe.1999.1311

\section{Tarpy, D.R., Keller, I.J., Caren, J.R., \& Delaney, D.A. (20 I I).} Experimentally induced variation in the physical reproductive potential and mating success in honey bee queens. Insectes Sociaux, 58, 569-574. doi: 10.1007/s00040$011-0180-z$

Tarpy, D.R., Nielsen, R., \& Nielsen, D.I. (2004). A scientific note on the revised estimates of effective paternity frequency in Apis. Insectes Sociaux, 51, 203-204. doi: 1 0. I 007/s00040-004-0734-4

Tarpy, D.R., \& Seeley,T.D. (2006). Lower disease infections in honeybee (Apis mellifera) colonies headed by polyandrous vs monandrous queens. Naturwissenschaften, 93, 195-199. doi: | 0. | 007/s00 | |4-006-009|-4
Tarpy, D.R., vanEngelsdorp, D., \& Pettis, J.S. (20 I 3). Genetic diversity affects colony survivorship in commercial honey bee colonies. Naturwissenschaften, 100, 723-728. doi: 10.1007/s00 I |4-013-1065-y

Theis, F..., Ugelvig, L.V., Marr, C., \& Cremer, S. (20I5). Opposing effects of allogrooming on disease transmission in ant societies. Philosophical Transactions of the Royal Society B: Biological Sciences, 370, 20140 I 08. doi: 10. 1098/rstb.2014.0108

Toufailia, H.M.A., Amiri, E., Scandian, L., Kryger, P., \& Ratnieks, F.L.W. (20|4). Towards integrated control of varroa: Effect of variation in hygienic behaviour among honey bee colonies on mite population increase and deformed wing virus incidence. Journal of Apicultural Research, 53, 555-562 doi: I0.3896/IBRA. I.53.5.10

Tragust, S., Mitteregger, B., Barone, V., Konrad, M., Ugelvig, L.V. \& Cremer, S. (2013). Ants disinfect fungus-exposed brood by oral uptake and spread of their poison. Current Biology, 23.76-82. doi:10.1016/j.cub.2012.11.034

Traniello, J.F.A., Rosengaus, R.B., \& Savoie, K. (2002). The development of immunity in a social insect: Evidence for the group facilitation of disease resistance. Proceedings of the National Academy of Sciences of the United States of America, 99, 6838-6842. doi: 10.1073/pnas. 102176599

Trumbo, S.T., Huang, Z.Y., \& Robinson, G.E. (1997). Division of labor between undertaker specialists and other middleaged workers in honey bee colonies. Behavioral Ecology and Sociobiology, 41, I5 I-163. doi: I 0. I007/s002650050374

Vojvodic, S., Jensen, A.B., Markussen, B., Eilenberg, J., \& Boomsma, J.. (20I I). Genetic variation in virulence among chalkbrood strains infecting honeybees. PLoS One, 6, e25035. doi: 10.137 I/journal.pone.0025035

Walker,T.N., \& Hughes, W.O.H. (2009). Adaptive social immunity in leaf-cutting ants. Biology Letters, 5, 446-448. doi: | 0.1098/rsbl.2009.0107

Ward, K., Danka, R., \& Ward, R. (2008). Comparative performance of two mite-resistant stocks of honey bees (Hymenoptera: Apidae) in alabama beekeeping operations. Journal of Economic Entomology, 101, 654-659. doi: I 0. I 603/0022-0493(2008) I 0 [ [654:CPOTMS]2.0.CO;2

Westra, E.R., van Houte, S., Oyesiku-Blakemore, S., Makin, B., Broniewski, J.M., Best, A., ... Buckling, A. (20 I5). Parasite exposure drives selective evolution of constitutive versus inducible defense. Current Biology, 25, I043-1049.

Wilson-Rich, N., Spivak, M., Fefferman, N.H., \& Starks, P.T. (2009). Genetic, individual, and group facilitation of disease resistance in insect societies. Annual Review of Entomology, 54, 405-423. doi: I 0. I | 46/annurev.ento.53. 103 | 06.09330

Wilson-Rich, N.,Tarpy, D.R., \& Starks, P.T. (20I2). Withinand across-colony effects of hyperpolyandry on immune function and body condition in honey bees (Apis mellifera). Journal of Insect Physiology, 58, 402-407. doi: I 0. $1016 /$ j. jinsphys.201।.12.020

Wilson, M.B., Spivak, M., Hegeman, A.D., Rendahl, A., \& Cohen, J.D. (20।3). Metabolomics reveals the origins of antimicrobial plant resins collected by honey bees. PLoS One, 8, e775 | 2. doi: 10.137|/journal.pone.00775 I2

Winston, M.L., Taylor, O.R., \& Otis, G.W. (1983). Some differences between temperate European and tropical African and South American honey bees. Bee World, 64 |2-2I. doi: | 0. I 080/0005772X.1983.I 1097902

Zhukovskaya, M.,Yanagawa, A., \& Forschler, B.T. (2013). Grooming behavior as a mechanism of insect disease defense. Insects, 4, 609-630.

Michael Simone-Finstrom Honey Bee Breeding, Genetics and Physiology Laboratory, USDA-ARS, 1157 Ben Hur Rd., Baton Rouge, LA 70820, USA E-mails: Michael.SimoneFinstrom@ars. usda.gov, m.simonefinstrom@gmail.com (iD) http://orcid.org/0000-0003-2938-9788

\section{Eva Crane's classic "World history..."}

This comprehensive book is the first to explore in detail the world history of man's use of bees from prehistoric times to the present day. It gathers together a vast amount of information in an eminently readable text. From archaeological evidence about bee hives in Ancient Egypt to the Maya people of Mesoamerica who kept stingless bees, Dr Crane recognises the variations in methods and yet there are some uncanny similarities. It wasn't until the 1600 that beekeeping techniques started to change in Europe, which culminated in 1851 with Langstroth's moveable frame hives being produced in the USA. The subsequent changes in beekeeping, based on scientific knowledge, brings the history up to date. There are over 500 illustrations and extensive bibliographies and appendices.

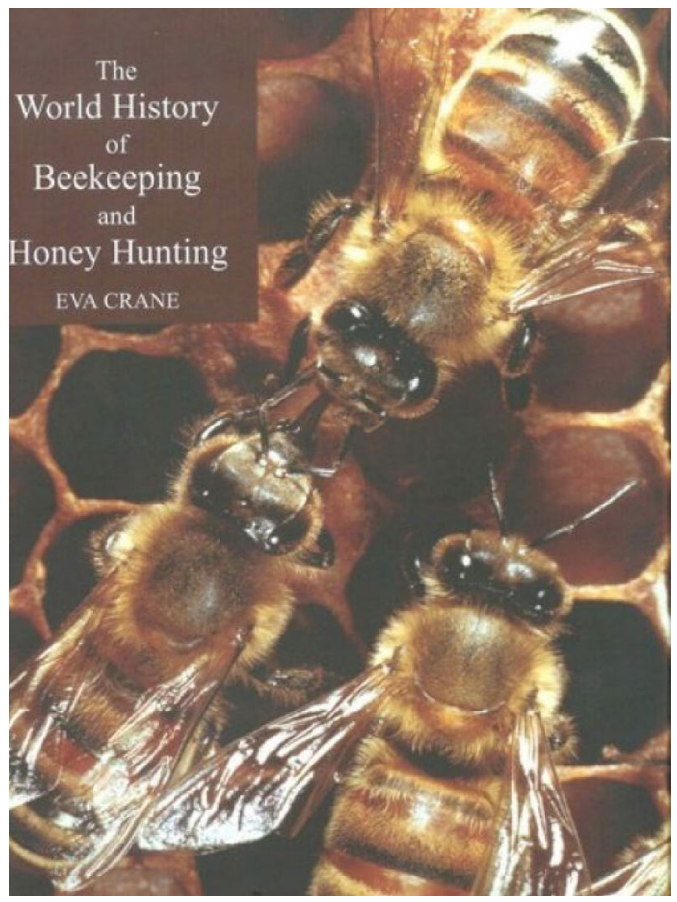

Available from the IBRA Bookshop for

$£ 99.00$ plus postage

ibrabee.org.uk 